\title{
It's about me! My approach to autoethnography
}

\author{
"auto = self; \\ ethno = culture; \\ graphy = research" (Emerald \& Carpenter, 2017, p. \\ 28).
}

Autoethnography is about me as the writer and researcher exploring my lived experiences (Ballard, 2009; Ritchie et al., 2013) as a form of storytelling (Jones, 2003). It is a genre of writing that "shows struggle, passion, [and] embodied life" (Ellis \& Bochner, 2006, p. 433) and provides "highly personalised accounts that draw upon the experience of the author/researcher" (Sparkes, 2000, p. 21). For Emerald and Carpenter (2017):

Autoethnography asserts that when we publicly story our experiences, they transcend the private and the personal and assume political import. It is a particular research method that connects the personal to the political, social and cultural in captivating, stirring and most importantly, insightful ways that move us to action (p. 27). 
Autoethnography is "...exploring the cultural/social/political through deep reflection on the personal. The pivotal next step, though, is looking out, from the personal to the cultural, gaining research insight and stimulating some form of transformative action" (Emerald \& Carpenter, 2017 , p. 28). For Indigenous peoples, storytelling is an essential form of communication (King, 2005) and knowledge transmission (Cuthers, 2019; Jackson, 2007; Rangiwai, 2018d, 2018q, 2021b; Rose, 2000) that has been identified as a powerful instrument in Indigenous research (Swadener \& Mutua, 2008).

Autoethnography develops "from the inside of the author to an outward expression, while working to take the readers inside themselves and ultimately out again" (Jones, 2003, p. 115). Whitinui (2014) opines: "Grounded within a resistance-based discourse, indigenous autoethnography aims to address issues of social justice and to develop social change by engaging indigenous researchers in rediscovering their own voices as "culturally liberating human-beings"” (Whitinui, 2014, p. 456). I have developed an autoethnographic approach, as a means of reclaiming and expressing my Indigenous voice, visibility, and vision (Battiste, 2000; Smith, 2005, Whitinui, 2014), based on the concepts of mōhiotanga, mātauranga, and māramatanga. Although the framework for this approach to autoethnography is presented formally for the first time here in this paper, I have used this approach in an informal way for a number of years (Enari \& Rangiwai, 2021; Haurua \& Rangiwai, 2020; Rangiwai, 2011a, 2011b, 2012, 2017a, 2017b, 2017c, 2018a, 2018b, 2018c, 2018d, 2018e, 2018f, 2018g, 2018h, 2018i, 2018j, 2018k, 20181, 2018m, 
2018n, 2018o, 2018p, 2018q, 2018r, 2018s, 2018t, 2018u, 2018v, 2019a, 2019b, 2019c, 2019d, 2019e, 2020a, 2020b, 2020c, 2020d, 2020e, 2020f; 2021a, 2021b, 2021c; Rangiwai \& Sciascia, 2021; Rangiwai et al., 2019; Rangiwai et al., 2020a, 2020b; Rangiwai et al., 2021).

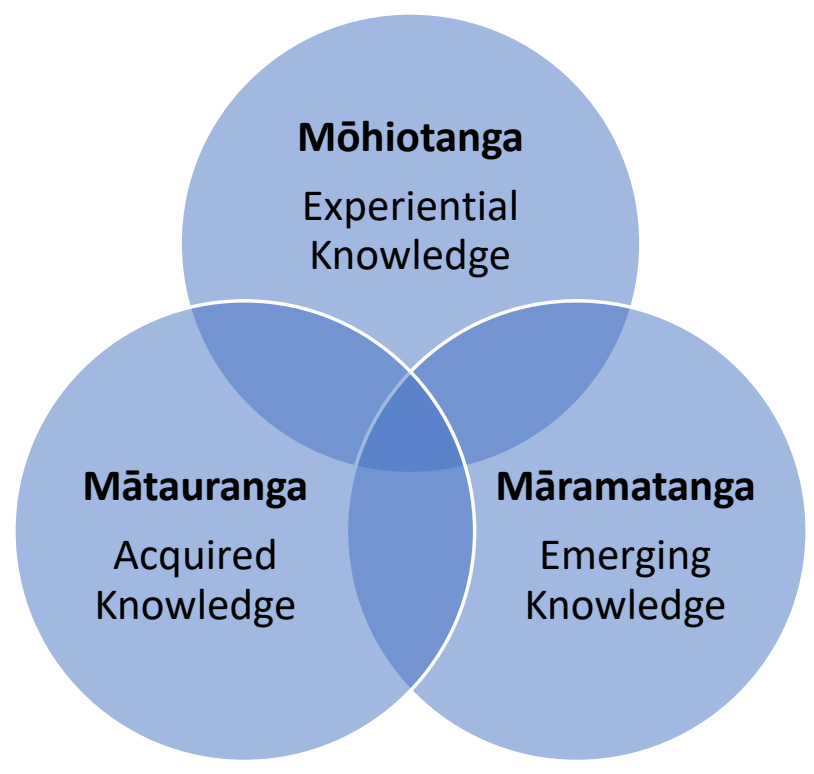

Figure 1: Mōhiotanga, Mātauranga and Māramatanga

Mōhiotanga describes knowledge, knowing, understanding, intelligence, awareness, insight, and perception (Moorfield, 2011). Mātauranga describes knowledge, wisdom, and understanding, and māramatanga describes enlightenment, insight, understanding, light, meaning, significance, and brainwave (Moorfield, 2011). In this framework, I define mōhiotanga as experiential knowledge, 
mātauranga as acquired knowledge, and māramatanga as emerging knowledge.

Through the interaction of mōhiotanga, mātauranga, a Māori researcher may move into a phase of māramatanga where new and emerging knowledge is revealed or constructed. This approach, therefore, allows Māori to write their stories in ways that include and reflect upon lived experiences, backed up by acquired knowledge from the literature and elsewhere, to discover or create new knowledge. Of course, learning is never-ending, which means that the cycle of mōhiotanga, mātauranga, and māramatanga, is continuous. 


\section{References}

Ballard, R. (2009). Granpa's call: Conscience, ethics, and aporias. Qualitative Inquiry, 15, p. 467-482.

Battiste, M. (2000). Reclaiming indigenous voice and vision. Seattle, WA: University of Washington Press. Cuthers, W. (2019). The significance of stories. Te Kaharoa: The eJournal on Indigenous Pacific Issues, 12(1), $1-12$. https://www.tekaharoa.com/index.php/tekaharoa /article/view/266

Ellis, C. \& Bochner, A. (2006). Analyzing analytic autoethnography: An autopsy. Journal of Contemporary Ethnography, 35, pp. 429-449.

Emerald, E. \& Carpenter, L. (2017). Autoethnography: Is my own story narrative research? In R. Dwyer, I. Davis \& E. Emerald (eds.), Narrative research in practice: Stories from the field (pp. 27-46). Springer.

Enari, D. \& Rangiwai, B. W. (2021). Digital innovation and funeral practices: Māori and Samoan perspectives during the COVID-19 pandemic. AlterNative: An International Journal of Indigenous Peoples, $1-6$. https://doi.org/10.1177/11771801211015568

Haurua, J., \& Rangiwai, B. (2020). Digital marketing in Māori higher education: A case study of Te Wānanga o Aotearoa. Te Kaharoa: The eJournal on Indigenous Pacific Issues, 15(1), 1-21. https://www.tekaharoa.com/index.php/tekaharoa /article/view/302

Jackson, M. (2007). Globalisation and the colonising state of mind. In M. Bargh (Ed.), Resistance: An indigenous response to neoliberalism (pp. 167-182). Wellington, New Zealand: Huia.

Jones, S. H. (2003). The way we were, are and might be: Torch singing as autoethnography. In Y. S. Lincoln 
\& N. K. Denzin (Eds.), Turning points in qualitative research: Tying the knots in a handkerchief (pp. 105118). Walnut Creek, CA: AltaMira Press.

King, T. (2005). The truth about stories: A native narrative.

Minneapolis, MN: University of Minnesota Press.

Moorfield, J. C. (2011). Te Aka - Māori-English, EnglishMãori dictionary. Auckland, New Zealand: Pearson.

Rangiwai, B. (2011a). 'Race' and the politics of land loss:

Colonising discourses for

Patuheuheu and Ngāti Haka. Te Kaharoa: The eJournal of Indigenous Pacific Issues, 4 (1), 40-96. https://www.tekaharoa.com/index.php/tekaharoa /article/view/112

Rangiwai, B. (2011b). Te Umutaoroa, Patuheuheu and Ngāti Haka: Towards a

prophetic model for unity and transformation. Te Kaharoa: The eJournal of Indigenous Pacific Issues, 4 $1-32$.

https://www.tekaharoa.com/index.php/tekaharoa article/view/110

Rangiwai, B. (2012). The potential of prophecy: Māori prophetism and community development. Te Kaharoa: The eJournal of Indigenous Pacific Issues, 1(1), Special Edition 1, 69-85. https://www.tekaharoa.com/index.php/tekaharoa /article/view/96

Rangiwai, B. (2017a). The critical theory of Te Kooti Arikirangi Te Turuki. Te Kaharoa: The eJournal on Indigenous Pacific Issues, 1O(1), 194240. https://www.tekaharoa.com/index.php/teka haroa/article/view/165

Rangiwai, B. (2017b). Māori prophetic movements as sites of political resistance: A case study. Te Kaharoa: The eJournal on Indigenous Pacific Issues, 1O(1), 
192. https://www.tekaharoa.com/index.php/teka haroa/article/view/160

Rangiwai, B. (2017c). Te Umutaoroa - the slow-cooking earth oven: A case study of intergenerational transference. Te Kaharoa: The eJournal on Indigenous Pacific Issues, 10(1), 241275. https://www.tekaharoa.com/index.php/teka haroa/article/view/168

Rangiwai, B. (2018a). Atuatanga. Te Kaharoa: The eJournal on Indigenous Pacific Issues, 11(1), 222224.

https://www.tekaharoa.com/index.php/tekaharoa Larticle/view/209

Rangiwai, B. (2018b). The Atuatanga model: A methodology for researching Māori theology. Te Kaharoa: The eJournal on Indigenous Pacific Issues, 11(1), 181-194. https://www.tekaharoa.com/index.php/tekaharoa /article/view/191/164

Rangiwai, B. (2018c). Atuatanga and syncretism: A view of Māori theology. Te Kaharoa: The eJournal on Indigenous Pacific Issues, 11(1), 653-661. https://www.tekaharoa.com/index.php/tekaharoa /article/view/242

Rangiwai, B. (2018d). "God is..." : A personal theology based on stories from my grandmother. Te Kaharoa: The eJournal on Indigenous Pacific Issues, 11(1), 171-172.

https://www.tekaharoa.com/index.php/tekaharoa /article/view/179/159

Rangiwai, B. (2018e). Hana Kōkō: What's wrong with Nelson's Māori Santa? Te Kaharoa: The eJournal on Indigenous Pacific Issues, 11(1), 676-684. https://www.tekaharoa.com/index.php/tekaharoa Larticle/view/244 
Rangiwai, B. (2018f). "Hell... unless they repent of their sins and turn to God": The problem of Bible translation and the potential impacts of Israel Folau's comments on Māori and Pasifika minority sexualities. Te Kaharoa: The eJournal on Indigenous Pacific Issues, 11(1), 250-282. https://www.tekaharoa.com/index.php/tekaharoa /article/view/214

Rangiwai, B. (2018g). Hereditary entanglement whakapapa and genealogical locatedness in Māori research: A researcher's personal experience. Te Kaharoa: The eJournal on Indigenous Pacific Issues, 11(1), 139-170. https://www.tekaharoa.com/index.php/tekaharoa /article/view/177/158

Rangiwai, B. (2018h). The impacts of contemporary embalming practices on tikanga Māori. Te Kaharoa: The eJournal on Indigenous Pacific Issues, 11(1), 229-249.

https://www.tekaharoa.com/index.php/tekaharoa /article/view/213

Rangiwai, B. (2018i). Ka mua, ka muri: A new transformative leadership theory based on a prophecy by Te Kooti Arikirangi Te Turuki. Te Kaharoa: The eJournal on Indigenous Pacific Issues, 11(1), 604-637.

https://www.tekaharoa.com/index.php/tekaharoa Larticle/view/239

Rangiwai, B. (2018j). Karaititanga: Some reflections on my Christology. Te Kaharoa: The eJournal on Indigenous Pacific Issues, 11(1), 591-603. https://www.tekaharoa.com/index.php/tekaharoa Larticle/view/238

Rangiwai, B. (2018k). Ko au ko te taiao, ko te taio ko au - I am the environment and the environment is me: 
A Māori theology of the environment. Te Kaharoa: The eJournal on Indigenous Pacific Issues, 11(1), 638-652.

https://www.tekaharoa.com/index.php/tekaharoa Larticle/view/241

Rangiwai, B. (20181). Mixed-up theology. Te Kaharoa: The eJournal on Indigenous Pacific Issues, 11(1), 175176.

https://www.tekaharoa.com/index.php/tekaharoa /article/view/184

Rangiwai, B. (2018m). My emerging theology. Te Kaharoa: The eJournal on Indigenous Pacific Issues, 11(1), 337 -

365. https://www.tekaharoa.com/index.php/teka haroa/article/view/231

Rangiwai, B. (2018n). A reflection on Priscilla Queen of the Desert. Te Kaharoa: The eJournal on Indigenous Pacific Issues, 11(1), 493-497. https://www.tekaharoa.com/index.php/tekaharoa Larticle/view/230

Rangiwai, B. (20180). Rangahau and transformative leadership. Te Kaharoa: The eJournal on Indigenous Pacific Issues, 11(1), 662-675. https://www.tekaharoa.com/index.php/tekaharoa /article/view/243

Rangiwai, B. (2018p). Reflections on The Book of Mormon musical: Flirtations with Mormon theology. Te Kaharoa: The eJournal on Indigenous Pacific Issues, 11(1), 283-318. Retrieved: https://www.tekaharoa.com/index.php/tekaharoa /article/view/215

Rangiwai, B. (2018q). "Stories are knowledge, and knowledge is literature": Viewing and re-viewing sites/cites of mātauranga Māori as an alternative to traditional Western literature reviews. Te Kaharoa: 
The eJournal on Indigenous Pacific Issues, 11(1), 489-492.

https://www.tekaharoa.com/index.php/tekaharoa /article/view/229

Rangiwai, B. (2018r). Syncretism in Māori theology. Te Kaharoa: The eJournal on Indigenous Pacific Issues, 11(1), 177-180.

https://www.tekaharoa.com/index.php/tekaharoa /article/view/186/162

Rangiwai, B. (2018s). Tangihanga. Te Kaharoa: The eJournal on Indigenous Pacific Issues, 11(1), 173174.

https://www.tekaharoa.com/index.php/tekaharoa /article/view/182/160

Rangiwai, B. (2018t). Te Kooti's slow-cooking earth oven prophecy: A Patuheuheu account and a new transformative leadership theory. Te Kaharoa: The eJournal on Indigenous Pacific Issues, 11(1), 1-119. https://www.tekaharoa.com/index.php/tekaharoa /article/view/240

Rangiwai, B. (2018u). Te Umutaoroa: A model for Patuheuheu hapū development. Te Kaharoa: The eJournal on Indigenous Pacific Issues, 11(1), 21-100. https://www.tekaharoa.com/index.php/tekaharoa /article/view/176

Rangiwai, B. (2018v). Te Umutaoroa: A Patuheuheu research model. Te Kaharoa: The eJournal on Indigenous Pacific Issues, 11(1), 1-20. https://www.tekaharoa.com/index.php/tekaharoa /article/view/169/153

Rangiwai, B. (2019a). Kākahu and gown: The incorporation of kākahu into academical dress in Aotearoa New Zealand with an example of a kākahu worn by a City University of New York graduation ceremony in 2006 - an interview with Sarah Smith. 
Te Kaharoa: The eJournal on Indigenous Pacific Issues, 12(1), $1-27$. https://www.tekaharoa.com/index.php/tekaharoa /article/view/246

Rangiwai, B. (2019b). The spectacle of the queer "Other": Māori gay(zing) at the $41^{\text {st }}$ Sydney Gay and Lesbian Mardi Gras 2019. Te Kaharoa: The eJournal on Indigenous Pacific Issues, 12(1), 1-13. https://www.tekaharoa.com/index.php/tekaharoa /article/view/267

Rangiwai, B. (2019c). My syncretistic faith-world perspective. Te Kaharoa: The eJournal on Indigenous Pacific Issues, 12(1), 1-92. https://www.tekaharoa.com/index.php/tekaharoa Larticle/view/279

Rangiwai, B. (2019d). Wānanga habits: The academical dress of Te Wānanga o Aotearoa - notes and images. Te Kaharoa: The eJournal on Indigenous Pacific Issues, 12(1), $1-20$. https://www.tekaharoa.com/index.php/tekaharoa /article/view/268

Rangiwai, B. (2019e). "Write(Right) the World": The benefits of publishing in Te Kaharoa: The eJournal on Indigenous Pacific Issues for Master of Applied Indigenous Knowledge students, 2018-2019. Te Kaharoa: The eJournal on Indigenous Pacific Issues, 12(1), 1-33. https://www.tekaharoa.com/index.php/tekaharoa /article/view/281

Rangiwai, B., Albert, M., Bell, T., Cuthers, W., Filisi, F., Hotereni, V., Lambert, C., Leuluai, R., SasaTepania, L., Walker, D. \& Yor, A. (2019). He Raranga Tangata: An Māori and Indigenous master's research supervision model derived from our experiences of the Master of Applied Indigenous 
Knowledge programme at Te Wānanga o Aotearoa in Māngere. Te Kaharoa: The eJournal on Indigenous Pacific Issues, 12(1), 1-13. https://www.tekaharoa.com/index.php/tekaharoa /article/view/283

Rangiwai, B. (2020a). The impacts of COVID-19 on hongi and the advent of the 'East Coast Wave'. In Te Kaharoa: The eJournal on Indigenous Pacific Issues, 15(1), $1-14$.

https://www.tekaharoa.com/index.php/tekaharoa /article/view/289

Rangiwai, B. (2020b). The impacts on tikanga of the Hindu practice of scattering human ashes into waterways compared with the practice of disposing of blood via the wastewater system as part of the arterial embalming process. Te Kaharoa: The eJournal on Indigenous Pacific Issues, 15(1), 1-24. https://www.tekaharoa.com/index.php/tekaharoa article/view/288

Rangiwai, B. (2020c). "My heart goes shut up, shut up!": Gay marriage to an Indian man-one year on. Te Kaharoa: The eJournal on Indigenous Pacific Issues, 15(1), $1-16$.

https://www.tekaharoa.com/index.php/tekaharoa /article/view/286

Rangiwai, B. (2020d). The potential effects of COVID-19 on research interviews in Year 2 of the Master of Applied Indigenous Knowledge programme at $\mathrm{Te}$ Wānanga o Aotearoa in Māngere. Te Kaharoa: The eJournal on Indigenous Pacific Issues, 15(1), 1-13. https://www.tekaharoa.com/index.php/tekaharoa /article/view/306

Rangiwai, B. (2020e). Supervision in the Master of Applied Indigenous Knowledge programme at Te Wānanga o Aotearoa in Māngere. Te Kaharoa: The 
eJournal on Indigenous Pacific Issues, 15(1), 1-11. https://doi.org/10.24135/tekaharoa.v15i1.307

Rangiwai, B. (2020f). Facebook as a substitute for kanohi ki te kanohi in the Master of Applied Indigenous Knowledge programme at Te Wānanga o Aotearoa in Māngere. Te Kaharoa: The eJournal on Indigenous Pacific Issues, 15(1), 1-17. https://www.tekaharoa.com/index.php/tekaharoa /article/view/309

Rangiwai, B., Simati-Kumar, B. \& Mataroa, R. (2020a). The He Waka Hiringa Map 2020-2021: Using He Raranga Tangata to support the implementation of the He Waka Hiringa Map in the Master of Applied Indigenous Knowledge programme at Te Wānanga o Aotearoa in Māngere. Te Kaharoa: The eJournal on Indigenous Pacific Issues, 15(1), 1-12. https://www.tekaharoa.com/index.php/tekaharoa Larticle/view/294

Rangiwai, Simati-Kumar, B., Mataroa, R. (2020b). The impacts of COVID-19 on the 2020 cohort of the Master of Applied Indigenous Knowledge programme at Te Wānanga o Aotearoa in Māngere. Te Kaharoa: The eJournal on Indigenous Pacific Issues, $15(1)$ $1-21$. https://www.tekaharoa.com/index.php/tekaharoa Larticle/view/301

Rangiwai, B. (2021a). Edward Fitzgerald-pioneer, coach driver, shepherd, and rabitter: A very brief reflection. Te Kaharoa: The eJournal on Indigenous Pacific Issues, 17(1), 1-11. https://www.tekaharoa.com/index.php/tekaharoa article/view/338

Rangiwai, B. (2021b). Nan's stories. Te Kaharoa: The eJournal on Indigenous Pacific Issues, 17(1), 1-22. https://doi.org/10.24135/tekaharoa.v17i1.347 
Rangiwai, B. (2021c). Tama-ki-Hikurangi: A whare built for Te Kooti. Te Kaharoa: The eJournal on Indigenous Pacific Issues, 17(1), 1-25. https://www.tekaharoa.com/index.php/tekaharoa /article/view/340

Rangiwai, B., Enari, D., Masae, C., Paea, D., TahilanuMapili, L. \& Vailahi, V. (2021). Lost in translation: Reflexive thematic analysis in research with Pacific peoples. Te Kaharoa: The eJournal on Indigenous Pacific Issues, 17(1). https://www.tekaharoa.com/index.php/tekaharoa /article/view/354

Rangiwai, B. W. \& Sciascia, A. D. (2021). The impacts of COVID-19 on tangihanga. Journal of Global Indigeneity, 5(1), 1-14. https://www.journalofglobalindigeneity.com/articl e/19435-the-impacts-of-covid-19-on-tangihanga

Ritchie, J., Morrison, S., Vaioleti, T. \& Ritchie, T. (2013). Transgressing boundaries of private and public: Auto-ethnography and intercultural funerals. Studies in Symbolic Interaction, 40, pp. 95-126.

Rose, D. B. (2000). Dingo makes us human: Life and land in an Australian Aborginal culture. Cambridge, UK: Cambridge University Press.

Simati-Kumar, B. \& Rangiwai, B. (2020). A plan for online teaching and learning for the Master of Applied Indigenous Knowledge (MAIK) programme in Māngere: Responding to COVID-19. Te Kaharoa: The eJournal on Indigenous Pacific Issues, 15(1), 1-14. https://www.tekaharoa.com/index.php/tekaharoa article/view/290

Smith, L. T. (2005). On tricky ground: Researching the native in the age of uncertainty. In N. K. Denzin \& Y. S. Lincoln (Eds.), The Sage handbook of 
qualitative research (3rd ed., pp. 85-107). Thousand Oaks, CA: Sage.

Sparkes, A. (2000). Autoethnography and narratives of self: Reflections on critical action. Sociology of Sport Journal, 17(1), p. 21-43.

Swadener, B. B. \& Mutua, K. (2008). Decolonizing performances: Decontructing the global postcolonial. In N. K. Denzin, Y. S. Lincoln \& L. T. Smith (Eds.), Handbook of critical and indigenous methodologies (pp. 31-43). Los Angeles, CA: Sage.

Whitinui, P. (2014). Indigenous autoethnography: Exploring, engaging, and experiencing "self" as a native method of inquiry. Journal of Contemporary Ethnography, 43(4), pp. 456-487. 